\title{
MANAJEMEN LABA, TATA KELOLA DAN NILAI PERUSAHAAN
}

\author{
SHEVIN WINARTA \\ IRENE NATALIA \\ DEDHY SULISTIAWAN
}

\author{
Universitas Surabaya, Jalan Raya Kalirungkut, Surabaya, Jawa Timur, Indonesia \\ irenenatalia@staff.ubaya.ac.id
}

\begin{abstract}
The purpose of this study is to empirically determine the effect of earnings management and corporate governance practices on firm value. Modified Jones-based discretionary accruals are used as a proxy for earnings management. Firm value is measured by Tobin's $Q$ and corporate governance is evaluated by independent commissioners, managerial ownership, institutional ownership, and auditor reputation. The study uses companies listed in Indonesia Stock Exchange for the 2017-2019 period. The main findings indicate that earnings management has a positive effect on firm value and institutional ownership is able to weaken the effect of earnings management on firm value. This study contributes to market-based accounting research and corporate governance.
\end{abstract}

Keywords: Earnings management, corporate governance, firm value, institusional ownership

Abstrak: Tujuan penelitian ini adalah untuk mengetahui secara empiris pengaruh manajemen laba dan praktik tata kelola perusahaan terhadap nilai perusahaan pada perusahaan. Akrual diskresioner berbasis modified Jones digunakan sebagai proksi dari manajemen laba. Nilai perusahaan menggunakan Tobin's $Q$ dan tata kelola perusahaan dievaluasi dengan proksi komisaris independen, kepemilikan manajerial, kepemilikan institusional, dan reputasi auditor. Sampel studi ini adalah emiten Bursa Efek Indonesia periode 2017-2019. Temuan utama penelitian ini menunjukkan bahwa manajemen laba berpengaruh positif terhadap nilai perusahaan dan kepemilikan institusional mampu memperlemah pengaruh manajemen laba terhadap nilai perusahaan. Studi ini berkontribusi terhadap riset akuntansi berbasis pasar dan tata kelola perusahaan.

Kata kunci: Manajemen laba, tata kelola perusahaan, nilai perusahaan, kepemilikan institusional

\section{PENDAHULUAN}

Salah satu target utama perusahaan adalah menaikkan nilai perusahaan melalui pemilihan manajemen untuk berbagai proyek yang paling berdampak pada penambahan kesejahteraan investor (Brigham, 2007:409). Keputusan manajemen diharapkan akan berdampak pada nilai perusahaan.

Manajemen sebagai agen dapat melakukan pengelolaan laba, agar memiliki nilai perusahaan yang baik. Manajemen laba adalah tindakan untuk menaikkan, menurunkan, ataupun pemerataan laba pada laporan keuangan perusahaan (Scott, 2015:445). Salah satu bentuk penyimpangan yang seringkali dilakukan untuk memengaruhi laba pada laporan keuangan perusahaan disebut juga dengan manajemen laba (Herawaty, 2008). Meskipun tidak selalu illegal, raktik manajemen laba diyakini bisa memberikan efek negatif pada kepercayaan 
masyarakat ataupun investor terhadap perusahaan melalui penurunan harga sahamnya.

Untuk melindungi prinsipal perusahaan, tata kelola perusahaan menjadi suatu upaya untuk mengurangi kapasitas manajemen guna menjalankan praktik manajemen laba (Klein, 2002; Peasnell et al., 2000). Tata kelola perusahaan ialah suatu sistem yang dibentuk guna mengontrol dan mengatur perusahaan. Sistem ini membatasi kebebasan manajemen untuk melakukan manajemen laba.

Yuniarti et al (2017), Abbas dan Usman (2019), dan Rahmawati dan Putri (2020) telah melakukan penelitian terdahulu terkait hubungan antara manajemen laba dengan nilai perusahaan.. Yuniarti et al (2017) dan Rahmawati dan Putri (2020) mengemukakan bahwa praktik manajemen laba yang dilakukan oleh manajemen akan memberikan pengaruh negatif terhadap nilai perusahaan. Namun hal ini tidak sejalan dengan penelitian yang dilakukan oleh Abbas dan Usman (2019) yang menyatakan bahwa ketika pihak manajemen melakukan tindakan manajemen laba maka akan memebrikan pengaruh yang positif terhadap nilai perusahaan. Hubungan antara manajemen laba terhadap nilai perusahaan dimoderasi oleh komisaris independen dan kepemilikan institusional (Herawaty, 2008), serta reputasi auditor (Herawaty, 2008; Tarmidi dan Murwaningsari, 2019).

Penelitian ini diharapkan dapat memberi manfaat bagi stakeholder sebagai bahan pertimbangan dalam mengambil keputusan investasi serta menggunakan informasi akrual diskresioner untuk menilai pengelolaan laba manajemen perusahaan. Studi ini juga diharapkan berkontribusi menjelaskan pentingnya tata kelola yang baik sebagai upaya untuk mereduksi penurunan nilai perusahaan.

\section{Nilai Perusahaan}

Nilai perusahaan didefinisikan sebagai nilai pasar karena nilai perusahaan dapat memberikan kemakmuran pemegang saham secara maksimum apabila harga saham perusahaan meningkat. Berbagai kebijakan yang diambil oleh manajemen dalam upaya untuk meningkatkan nilai perusahaan melalui peningkatan kemakmuran pemilik dan para pemegang saham yang tercermin pada harga saham (Brigham dan Daves, 2007). Salah satu alternatif yang digunakan dalam menilai nilai perusahaan adalah dengan menggunakan Tobin's Q. Rasio ini merupakan konsep yang sangat berharga karena menunjukkan estimasi pasar keuangan saat ini tentang nilai hasil pengembalian dari setiap dolar investasi inkremental. Tobin's $Q$ dihitung dengan membandingkan rasio nilai pasar saham perusahaan dengan nilai buku ekuitas perusahaan.

\section{Manajemen Laba}

Manajemen laba adalah tindakan untuk menaikkan, menurunkan atau pemerataan laba pada laporan keuangan (Scott, 2015). Masalah keagenan tidak dapat dihindari ketika tujuan yang dimiliki oleh pihak agen dan prinsipal berbeda. Manajemen laba berdasarkan perspektifnya dibedakan menjadi dua, yaitu manajemen laba yang baik dan buruk (Scott, 2015), atau manajemen laba yang efisien dan oportunistik (Gunny, 2010; Cornett et al., 2009). Manajemen laba yang efisien ditunjukkan oleh meningkatnya nilai perusahaan, termasuk peningkatan labanya (Gunny, 2010), sehingga penghasilan dapat diprediksi, dan mereka dapat menjadi sinyal untuk peningkatan kualitas laba (Jara dan López, 2011). Manajemen laba oportunistik ditunjukkan oleh meningkatnya kemakmuran manajemen, orang dalam, serta pemegang saham pengendali. 
Ada lima faktor utama yang memotivasi pihak manajemen untuk menjalankan praktik manajemen laba (Scott, 2015):

1. Political Motivation

Perusahaan besar memiliki kecenderungan untuk menampilkan laba yang lebih rendah dengan harapan untuk mengurangi tingkat visibilitas disaat kesejahteraan perusahaan sedang mencapai level tertinggi. Hal ini dilakukan pihak manajemen agar perusahaan memperoleh fasilitas dan kemudahan dari pihak pemerintah.

2. Chief Executive Officer Turnover

Strategi untuk meningkatkan laba untuk memperoleh jumlah bonus secara maximal akan dilakukan oleh CEO yang masa kontraknya akan berakhir atau akan memasuki masa pensiun. Hal ini juga dilakukan oleh pihak manajemen yang menyadari bahwa performa mereka tidak baik.Tujuan dari dilakukan hal ini adalah untuk menghindari dari adanya kemungkinan dipecat sehingga mereka berusaha untuk memaksimalkan jumlah laba yang akan dilaporkan.

3. Debt covenant

Pihak manajemen akan cenderung untuk memindahkan laba pada periode selanjutnya ke periode yang sedang berjalan ketika sebuah perusahaan semakin dekat dengan deadline pelanggaran perjanjian hutang dengan harapan hal tersebut dapat meminimalkan kemungkinan perusahaan melakukan pelanggaran kontrak hutang.

4. Initial Public Offering

Penjualan saham pertama kali yang dilakukan oleh perusahaan ialah sumber informasi krusial untuk khalayak umum. Hal ini dapat memberikan signal kepada stakeholder terkait dengan nilai perusahaan yang bisa dilihat dari harga saham. Strategi menaikkan laba yang dilaporkan biasanya dijalankan oleh pihak manajemen untuk mempengaruhi keputusan yang akan dibuat oleh stakeholder.
5. Taxation Motivation

Untuk meminimalkan pajak yang harus dibayar kepada pemerintah, pihak manajemen akan berupaya untuk meminimalkan laba yang akan dilaporkan supaya pembayaran pajaknya semakin kecil.

Laporan keuangan menjadi tidak lagi relevan bagi penggunanya apabila terdapat indikasi adanya rekayasa yang dijalankan pihak manajemen terhadap laporan keuangan (Sulistyanto, 2018). Pengguna bisa menjadi kehilangan kepercayaan atas laporan keuangan karena masalah keagenan. Penelitian menurut Rahmawati dan Putri (2020) dan Yuniarti (2017) membuktikkan bahwa terdapat hubungan negatif antara manajemen laba terhadap nilai perusahaan. Studi ini berupaya mendukungnya. Mengacu pemaparan tersebut, dibuatlah hipotesis sebagai berikut:

$\mathrm{H} 1$ : Manajemen laba berpengaruh negatif terhadap nilai perusahaan.

\section{Tata Kelola Perusahaan}

Tata kelola perusahaan ialah suatu sistem yang dibentuk guna mengontrol serta mengatur perusahaan agar nilai perusahaan dapat ditingkatkan (Herawaty, 2008). Mekanisme tata kelola perusahaan apabila diterapkan dengan baik maka akan membatasi perilaku oportunistik manajemen, seperti melakukan manajemen laba, agar tidak menurunkan nilai perusahaan.

Berdasarkan masalah keagenan, tata kelola perusahaan bisa menjadi penunjang untuk memberikan keyakinan kepada stakeholder terkait dengan return atas investasi yang telah mereka berikan. Tata kelola perusahaan berbicara terkait bagaimana stakeholder memiliki keyakinan bahwa pihak manajemen akan memberikan return yang mereka harapkan, keyakinan bahwa pihak manajemen tidak akan menjalankan kecurangan yang bisa menjadikan stakeholder rugi dengan menggelapkan dana, mencuri dana, 
atau menginvestasikan ke proyek yang tidak memberikan stakeholder keuntungan sama sekali, keyakinan bahwa stakeholder mampu untuk mengontrol pihak manajemen agar berjalan sesuai dengan yang diharapkan. Mekanisme tata kelola perusahaan yang baik terdiri dari komisaris independen, kepemilikan manajerial, kepemilikan institusional, dan reputasi auditor.

\section{Komisaris Independen}

Dewan komisaris berwenang serta mempunyai tanggung jawab mengontrol serta mengawasi kegiatan serta kebijakan-kebijakan yang dilakukan oleh pihak manajemen atas pengelolaan dan pemanfaatan sumber daya agar efisien dan efektif serta bisa meraih tujuan organisasi yang sudah ditentukan (Fama dan Jensen, 1983). Jumlah atau proporsi komisaris independen dalam dewan komisaris mempengaruhi fungsi controlling dan monitoring yang dilakukan oleh komisaris independen (Vafeas, 2000). Klein (2002) membuktikan praktik manajemen laba lebih tinggi saat perusahaan memiliki persentase dewan komisaris yang lebih kecil. Komisaris independen menyelaraskan perbedaan kepentingan agen dan prinsipal. UUPT No. 40 tahun 2007 menyatakan bahwa seluruh perusahaan harus memiliki komisaris independen dalam susunan dewan komisaris. Herawaty (2008) dan Susanto (2013) membuktikan bahwa komisaris independen dapat dijadikan sebagai variabel moderasi untuk memperlemah pengaruh manajemen laba terhadap nilai perusahaan. Mengacu pemaparan tersebut maka dibuatlah hipotesis, yakni:

H2a: Pengaruh manajemen laba terhadap nilai perusahaan diperlemah dengan adanya komisaris independen.

\section{Kepemilikan Manajerial}

Kepemilikan saham oleh pihak manajemen berarti manajemen dapat terlibat dalam pengambilan keputusan perusahaan disebut juga dengan kepemilikan manajerial. Kepemilikan manajerial diyakini bisa meminimalisir permasalahan keagenan yang muncul dikarenakan dapat menyeimbangkan kepentingan antara pihak manajemen dan stakeholder (Jensen dan Meckling, 1976). Manajemen berperan sebagai agen sekaligus prinsipal, sehingga manajemen memiliki konflik kepentingan dalam pengelolaan perusahaan.

Jika kepemilikan manajerial besar, maka semakin besar kemungkinan manajemen untuk mengedepankan kepentingannya sebagai agen dapat diminimalkan dan mengurangi asimetri informasi. Saat kepemilikan manajerial rendah, cenderung memungkinkan peningkatan munculnya praktik manajemen laba (Shieifer dan Vishny, 1986). Kepemilikan manajerial mampu memperlemah keputusan manajer untuk melakukan praktik manajemen laba (Alzoubi, 2016).

Kepemilikan manajerial menjadi suatu mekanisme yang bisa menjadi pembatas perilaku oportunistik manajer untuk menjalankan manajemen laba sehingga dapat memperlemah tindakan manajemen untuk melakukan praktik manajemen laba terhadap nilai perusahaan (Midiastuty dan Machfoedz, 2003; Kamil dan Hapsari, 2014). Hal ini juga diperkuat dengan penelitian yang dilakukan oleh Ridwan dan Gunardi (2013) yang menyatakan bahwa kepemilikan manajerial mampu memoderasi hubungan antara manajemen laba dan nilai perusahaan. Mengacu pemaparan tersebut, dibuatlah hipotesis sebagai berikut:

$\mathrm{H} 2 \mathrm{~b}$ : Pengaruh manajemen laba terhadap nilai perusahaan diperlemah dengan adanya kepemilikan manajerial.

\section{Kepemilikan Institusional}

Investor institusional dianggap mampu menggunakan keuntungan dengan menggunakan informasi yang ada guna memprediksi laba pada periode mendatang daripada investor non institusional. Selain itu, 
kepemilikan institusional memiliki sumber daya untuk mengawasi kinerja perusahaan. Manajemen laba dapat diminimumkan dengan mekanisme pengawasan oleh kepemilikan institusional (Herawati, 2008). Berdasarkan penelitian dari Balsam et al (2002) mengemukakan, terdapat hubungan negatif antara manajemen laba dengan return yang bertepatan pada tanggal pengumuman dikarenakan investor institusional memiliki keuntungan terhadap akses sumber informasi. Nilai manajemen laba dapat diperlemah dengan adanya kepemilikan institusional menurut penelitian yang dikemukakan oleh Jiambavo et al (1996). Hal ini didukung dengan penelitian yang dilakukan oleh Midiastuty \& Machfoedz (2003) dimana memaparkan kepemilikan institusional yang tinggi dapat digunakan untuk membatasi tindakan manajer untuk melakukan earnings management dan mempunyai pengaruh untuk memperlemah hubungan antara manajemen laba terhadap nilai perusahaan. Hal ini juga diperkuat oleh penelitian yang dilakukan oleh Ridwan dan Gunardi (2013) yang membuktikkan bahwa kepemilikan institusional merupakan variabel moderasi untuk memperlemah hubungan manajemen laba dengan nilai perusahaan.

Jika manajemen laba tersebut efisien maka kepemilikan institusional yang tinggi akan meningkatkan manajemen laba tetapi jika manajemen laba yang dilakukan perusahaan bersifat oportunis maka kepemilikan institusional yang tinggi akan mengurangi manajemen laba. Mengacu pemaparan tersebut, dibuatlah hipotesis sebagai berikut:
$\mathrm{H} 2 \mathrm{c}$ : Pengaruh manajemen laba terhadap nilai perusahaan diperlemah dengan adanya kepemilikan institusional.

\section{Reputasi Auditor}

Auditor independen sebagai pihak ketika diperlukan kehadirannya untuk mediator hubungan antara pihak manajemen dengan stakeholder dikarenakan menurut teori keagenan manusia adalah makhluk yang self interest (Sinarwati, 2010). Apabila laporan keuangan diaudit oleh auditor yang memiliki reputasi yang kredibel maka stakeholder lebih memiliki kepercayaan bahwa laporan keuangan tersebut bebas dari terjadinya manajemen laba yang dijalankan pihak manajemen. Manajemen laba dapat diminimumkan dengan kualitas audit (Herawati, 2008; Susanto, Pradipta, \& Esther, 2021). Big Four Auditors dapat dijadikan sebagai variabel moderasi untuk memperlemah praktik manajemen laba terhadap nilai perusahaan (Herawati, 2008; Tarmidi dan Murwaningsari, 2019). Hal ini juga kembali diperkuat oleh penelitian yang dilakukan oleh Ridwan dan Gunardi (2013) yang pada penelitiannya membuktikan bahwa reputasi auditor mampu memperlemah pengaruh manajemen laba terhadap nilai perusahaan. Mengacu pemaparan tersebut, dibuatlah hipotesis sebagai berikut:

$\mathrm{H} 2 \mathrm{~d}$ : Pengaruh manajemen laba terhadap nilai perusahaan diperlemah dengan adanya reputasi auditor.

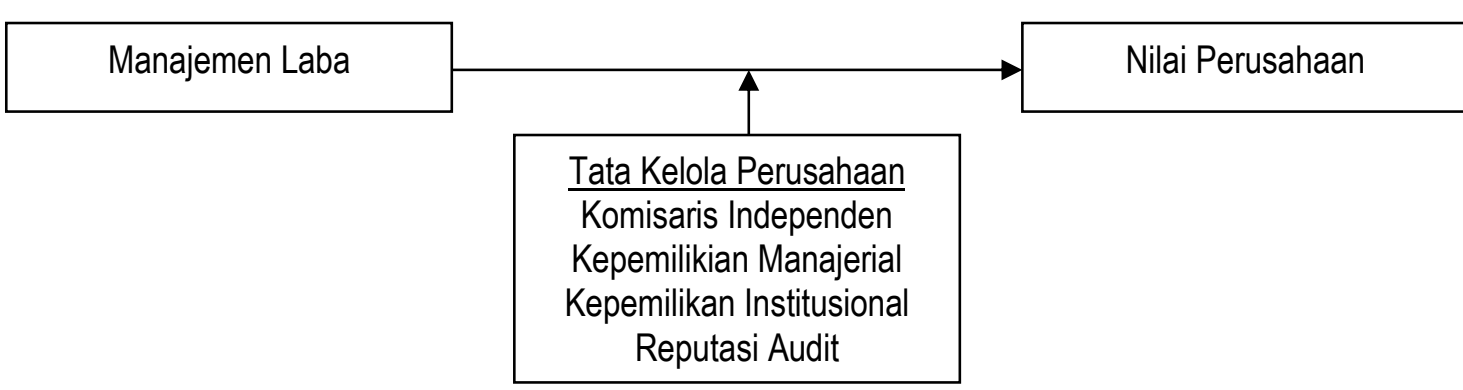

Gambar 1 Model Penelitian 


\section{METODE PENELITIAN}

Penelitian ini menggunakan pendekatan kuantitatif. Unit analisis yang digunakan adalah emiten yang teregistrasi pada Bursa Efek Indonesia (BEI) pada periode 20172019. Data diperoleh dari laporan keuangan tahunan emiten pada website www.idx.co.id.

Variabel bebas manajemen laba diproksikan dengan discretionary accrual yang dihitung memanfaatkan model Modified Jones (1995). Perhitungan discretionary accrual (Susanto, Pradipta, \& Cecilia, 2019; Susanto, Pirzada, \& Adrianne, 2019) dapat dihitung dengan rumus (1) sampai dengan (4):

TACCR $_{\text {it }}=E A R N-C F O$.

$\frac{T_{A C C R_{i t}}}{T \cdot A S S_{i t-1}}=\beta_{1}\left[\frac{1}{T \cdot A S S_{i t-1}}\right]+\beta_{2} \frac{\left[\Delta R E V_{i t}\right]}{T \cdot A S S_{i t-1}}+$

$\beta_{3} \frac{P P E_{i t}}{T_{. A S S_{i t-1}}}+e_{i t}$

$N D A_{i t}=\beta_{1}\left[\frac{1}{\text { T.ASSit-1 }}\right]+\beta_{2} \frac{\left[\Delta R E V_{i t}-\Delta R E C_{i t}\right]}{T . A S S i t-1}+$

$\beta_{3} \frac{P P E_{i t}}{\text { T.ASSit-1. }}$....

$D A_{i t}=\frac{T A C C R_{i t}}{T \cdot A S S_{i t-1}}-N D A_{i t}$

Keterangan:

$\mathrm{TACCR}_{\mathrm{it}}=$ Total akrual perusahaan $\mathrm{i}$ tahun $\mathrm{t}$

T.ASS $_{\text {it- } 1}=$ Total aset perusahaan $\mathrm{i}$ tahun $\mathrm{t}-1$

EARN = Laba bersih

CFO = Arus kas dari kegiatan operasi

$\mathrm{NDA}_{\text {it }}=$ Non discretionary accrual

$\mathrm{DA}_{\mathrm{it}} \quad=$ Discretionary accrual

DREV = Perubahan pendapatan dari tahun $\mathrm{t}-$ 1 ke tahun $t\left(R_{E V}-R_{t} E V_{t-1}\right)$

$\mathrm{DREC}=$ Perubahan piutang dari tahun $\mathrm{t}-1 \mathrm{ke}$ tahunt $\left(\mathrm{REC}_{\mathrm{t}}-\mathrm{REC}_{\mathrm{t}-1}\right)$

PPE = Nilai kotor aset tetap pada tahun $\mathrm{t}$

Variabel dependen nilai perusahaan diukur dengan Tobin's Q. Dengan menggunakan nilai pasar dan nilai buku ekuitasnya, pengukuran nilai perusahaan memanfaatkan rumus Tobin's $Q$ yakni:

$Q_{i t}=\frac{M V E_{i t}+D_{i t}}{B V E_{i t}+D_{i t}}$

Keterangan:

$\mathrm{Q} \quad=$ Nilai Perusahaan
MVE = Nilai pasar ekuitas (harga saham penutupan $\mathrm{x}$ jumlah saham beredar)

$\mathrm{D}=$ Nilai buku dari total hutang

BVE = Nilai buku dari ekuitas (total aset total kewajiban)

Variabel moderasi yang digunakan adalah tata kelola perusahaan. Tata Kelola perusahaan dapat memperlemah hubungan antara manajemen laba dengan nilai perusahaan. Penelitian ini menggunakan semua komponen mekanisme tata kelola, yaitu kepemilikan institusional, kepemilikan manajerial, komisaris independen, serta reputasi auditor. Komisaris independen diukur dengan menggunakan rasio dari total komisaris independen dibagikan dengan jumlah seluruh anggota dewan komisaris. Kepemilikan manajerial diukur menggunakan dummy variabel $(0=$ tidak ada kepemilikan manajerial. 1 = ada kepemilikan manajerial). Reputasi auditor diukur menggunakan dummy variable $(0=$ perusahaan yang tidak menggunakan Big Four Auditors, 1 = perusahaan menggunakan pengauditan Big Four Auditors). Kepemilikan institusional dilihat dari rasio total persentase kepemilikan saham pihak institusi dibagi dengan total total saham yang beredar.

Model penelitian yang digunakan ada dua, yaitu:

$Q_{i t}=a_{0}+a_{1} E m_{i t}+a_{2} U P_{i t}$ (Model 1).

$Q_{i t}=a_{0}+a_{1} E_{i t}+a_{2} K_{0 m l n d}+a_{3} K_{\text {epMan }}+$ $\mathrm{a}_{4} \mathrm{RA}_{\mathrm{it}}+\mathrm{a}_{5}$KKeplns $_{\mathrm{it}}+\mathrm{a}_{6} \mathrm{EM}^{*}$ Komlnd $_{i t}+$ $a_{7} E^{*} K_{e p M a n}+a_{8} E^{*} M^{*} A_{i t}+a_{9} E M^{*} K_{e p l n} s_{i t}+$ $a_{10} U P_{\text {it }}$ (Model 2).

\section{Keterangan:}

$\mathrm{EM}=$ Manajemen laba diproksi dengan akrual abnormal (DA).

Komlnd $=$ Persentase komisaris independen dibanding total dewan komisaris

KepMan= Kepemilikan manajerial

RA = Reputasi auditor

Keplns $=$ Kepemilikan institusional

$\mathrm{Q} \quad=$ Nilai Perusahaan (Tobin's $\mathrm{Q}$ ) 
UP = Ukuran perusahaan (log natural total

Metode pengambilan sampel ialah purposive sampling dengan kriteria yang digunakan meliputi:

1. Perusahaan yang listing di BEI kecuali sektor keuangan periode 2017, 2018, dan 2019.

\section{HASIL DAN PEMBAHASAN}

2. Perusahaan yang menerbitkan laporan tahunan (annual report) dan memiliki tahun berakhir pada 31 Desember pada periode penelitian.

3. Perusahaan yang mempunyai data terkait komisaris independen, kepemilikan manajerial, kepemilikan institusional dan reputasi auditor.

4. Mata uang fungsional perusahaan adalah rupiah.

Tabel 1 Hasil Statistik Deskriptif

\begin{tabular}{lcrrrr}
\hline \multicolumn{1}{c}{ Variabel } & N & Minimum & Maximum & \multicolumn{1}{c}{ Mean } & Std. Deviation \\
\hline Nilai Perusahaan (TobisnQ) & 655 & 0,2885 & 2,1250 & 1,050607 & 0,3760652 \\
Manajemen Laba (EM) & 655 & $-0,0749$ & 0,0833 & 0,003744 & 0,0217012 \\
Kepemilikan Manajerial (KepMan) & 655 & 0,0000 & 1,0000 & 0,62 & 0,487 \\
Kepemilikan Institusional (Keplns) & 655 & 0,0000 & 1,0000 & 0,626409 & 0,2580900 \\
Reputasi Auditor (RA) & 655 & 0,0000 & 1,0000 & 0,32 & 0,465 \\
Komisaris Independen (Komlnd) & 655 & 0,2000 & 0,8000 & 0,404321 & 0,1029651 \\
Ukuran Perusahaan (UP) & 655 & 24,9951 & 33,4945 & 28,733357 & 1,6073577 \\
Valid N (listwise) & 655 & & & & \\
\hline
\end{tabular}

Berdasarkan Tabel 1, jumlah sampel perusahaan sebanyak 295 perusahaan dengan total 885 observasi. Setelah data siap diolah, dilakukan uji asumsi klasik pada model. Hasil statistik deskriptif disajikan dalam Tabel 1. Standar deviasi Tobins $Q$ senilai 0,3760 dan rata-rata sejumlah 1,050 . Nilai perusahaan yang melebihi 1 memperlihatkan bahwa nilai perusahaan lebih besar daripada nilai aset perusahaan yang tercatat. Manajemen laba memiliki nilai rata-rata sebesar 0,0037 dengan standar deviasinya sebesar 0,0217 . Nilai ratarata dibawah satu serta nilai standar deviasi yang tinggi dibandingkan dengan rata-rata membuktikan bahwa perilaku manajemen laba yang dilakukan oleh pihak manajemen relatif rendah serta data manajemen laba pada penelitian ini bervariasi. Pada $62 \%$ sampel, dewan direksi dan komisaris memiliki saham. Kepemilikan saham oleh manajer diyakini dapat memperkecil masalah keagenan yang muncul. Pada kepemilikan institusional memiliki nilai rata-rata yaitu 0.6264 dan standar deviasi sebesar 0.2580 . Berdasarkan Tabel 1 sebanyak $32 \%$ perusahaan menggunakan KAP Big4 untuk mengaudit laporan keuangannya. Sebanyak $40,43 \%$ perusahaan sampel telah memiliki komisaris independen dalam struktur dewan komisaris. Hal ini sejalan dengan peraturan BAPEPAM yang mewajibkan proporsi komisaris independen minimal $30 \%$ dari total keseluruhan. Nilai rata-rata ukuran perusahaan adalah 28.7333 dengan standar deviasi 1.6073 . 
Tabel 2 Hasil Uji Statistik

\begin{tabular}{lcccccc}
\hline & \multicolumn{3}{c}{ Model Regresi 1 } & \multicolumn{3}{c}{ Model regresi 2 } \\
\hline & Koefisien & T & Sig. & Koefisien & T & Sig. \\
\hline (Constant) & $-0,636$ & $-2,538$ & $0,0055^{* *}$ & $-0,346$ & $-1,220$ & 0,1115 \\
Manajemen Laba & 0,925 & 1,433 & $0,076^{*}$ & $-0,415$ & $-0,124$ & 0,451 \\
Kepemilikan Manajerial & & & & $-0,001$ & $-0,017$ & 0,493 \\
Kepemilikan Institusional & & & & 0,116 & 2,044 & $0,205^{* *}$ \\
Reputasi Auditor & & & & 0,146 & 4,278 & $0,000^{* * *}$ \\
Komisaris Independen & & & $-0,011$ & $-0,080$ & 0,468 \\
Ukuran Perusahaan & 0,022 & 2,472 & $0,007^{* * *}$ & 0,008 & 0,802 & 0,2115 \\
Manajemen Laba x Kepemilikan Manajerial & & & & $-1,187$ & $-0,894$ & 0,227 \\
Manajemen Laba x Kepemilikan Institusional & & & & $-1,845$ & $-0,750$ & $0,000^{* * *}$ \\
Manajemen Laba x Reputasi Auditor & & & & 0,550 & 0,365 & 0,3575 \\
Manajemen Laba x Komisaris Independen & & & & 1,675 & 0,228 & 0,410 \\
Adjusted R squared & 0,010 & & $0,012^{* *}$ & 0,042 & & \\
F hitung & 4,418 & & & & & \\
\hline
\end{tabular}

${ }^{*},{ }^{* *},{ }^{* * *}$ signifikan pada level $10 \%, 5 \%$, dan $1 \%$

Hasil uji statistik disajikan dalam Tabel 2. Nilai adjusted $R$ square pada Tabel 2 untuk model regresi 1 yaitu sebesar 0,01 sedangkan untuk model regresi 2 yaitu sebesar 0,042 . Nilai adjusted $R$ square yang lebih tinggi membuktikan bahwa model regresi 2 lebik baik dalam menjelaskan variansi nilai perusahaan pada perusahaan sampel. Pada uji ANOVA, F hitung untuk kedua model regresi yaitu sebesar 0,000 . Tingkat signifikansi yang lebih kecil daripada 0,05 membuktikkan bahwa model regresi tersebut layak untuk digunakan.

Hasil pengujian model regresi 1 membuktikan bahwa manajemen laba memiliki pengaruh positif terhadap nilai perusahaan. Hal ini bertentangan dengan hipotesis 1 dimana berarti praktik manajemen laba yang dilakukan oleh perusahaan dapat meningkatkan nilai perusahaan. Hasil ini dapat terjadi karena manajer dapat menggunakan manajemen laba sebagai strategi untuk menarik investor dan calon investor. Teori akuntansi positif mengasumsikan bahwa manajer menggunakan kebijakan akuntansi dan tingkat kebijaksanaan tertentu untuk mencapai tingkat penghasilan yang ditargetkan. Untuk mewujudkannya, manajer menggunakan strategi manajemen laba, sehingga laba yang dilaporkan dapat meyakinkan stakeholders tentang nilai perusahaan. Hal ini akan memicu reaksi investor yang positif, seperti harga saham yang lebih tinggi, pengembalian yang lebih tinggi, risk yang lebih rendah dan return yang lebih tinggi untuk setiap risiko unit (Rudiawarni et al, 2017). Kegiatan manajemen laba memberi investor pandangan dalam menilai perusahaan lebih baik dan reaksi menunjukkan bahwa investor berpikir pendek dalam menanggapi informasi keuangan perusahaan (Tarmidi dan Murwaningsari, 2019).

Hasil pengujian model regresi 2 menyatakan bahwa hanya satu dari variabel mekanisme tata kelola perusahaan yaitu kepemilikan institusional diyakini daat memperlemah tindakan manajemen laba terhadap nilai perusahaan. Bertambah besar taraf kepemilikan institusional menjadikan bertambah menguatnya taraf pengendalian pihak eksternal terhadap perusahaan yang mana bisa mengurangi agency cost dalam perusahaan serta meningkatkan nilai perusahaan. Sebagai prinsipal yang 
sophisticated, institusi melakukan pengawasan yang memadai untuk kebijakan manajemen.

Variabel kepemilikan manajerial belum mampu memperlemah tindakan manajemen untuk melakukan tindakan manajemen laba. Hal ini terjadi karena tidak tersedianya cukup pengawasan saat pemilik memegang peranan menjadi agen atau terdapatnya kelonggaran aturan perusahaan. Saat semakin besar kepemilikan manajerial, maka semakin besar kemungkinan manajemen untuk mengelola perusahaan dengan cara terbaik dan bertanggung jawab, sehingga konflik kepentingan antara prinsipal dan agen menjadi berkurang. Kondisi tersebut berbeda dengan keadaan perusahaan sebagai sampel penelitian. Perusahaan sampel mayoritas memiliki proporsi kepemilikan manajerial relatif sangat kecil. Hal ini menyebabkan adanya kemungkinan manajemen dari kepemilikan kecil tersebut belum merasakan manfaat yang besar untuk mengurangi konfil kepentingan yang ada. Tindakan manajemen laba masih terjadi, karena kecenderungan manajemen kurang bertanggung jawab serta bertindak seenaknya.

Variabel komisaris independen belum mampu memperlemah tindakan manajemen untuk melakukan tindakan manajemen laba. Hal ini dapat terjadi karena pengangkatan komisaris independen dewan komisaris independen hanya sebatas memenuhi aturan yang berlaku karena menurut Undang Undang No. 40 Tahun 2007 tentang Perseroan Terbatas (UUPT) mengharuskan adanya kelembagaan komisaris agar tercapai tata kelola yang baik. Jumlah minimal anggota komisaris independen hanya sebesar $30 \%$, dan jumlah ini belum cukup tinggi untuk dapat mendominasi kebijakan yang diambil oleh dewan komisaris. Selain itu, proporsi kepemilikan manajerial yang kecil dapat menjadi salah satu penyebab manajemen masih adanya konflik kepentingan antara agen dan prinsipal. Hasil ini konsisten dengan penelitian Herawaty (2008).

Variabel reputasi auditor belum mampu memperlemah tindakan manajemen untuk melakukan tindakan manajemen laba. Manajemen laba dilakukan dengan memanfaatkan kebijakan manajemen, pilihan kebijakan akuntansi yang sesuai standar akuntansi, dan multi periode. Teknik manajemen laba riil dapat dilakukan dengan mengurangi iklan dan biaya lainnya, agar laba berada di tingkatan yang diinginkan manajemen. Auditor susah untuk mendeteksi adanya manajemen laba yang dilakukan oleh pihak manajemen karena tidak keseluruhan tindakan manajemen laba berujung pada kesalahan materialitas. Selain itu, banyak dari perusahaan sampel yang masih belum menggunakan KAP Big 4 maupun yang berafiliasi dengan KAP Big 4 dalam proses auditnya.

\section{PENUTUP}

Berdasarkan hasil pembahasan, artikel ini menghasilkan kesimpulan sebagai berikut. Pertama, manajemen laba berpengaruh positif terhadap nilai perusahaan. Manajemen laba diyakini mampu meningkatkan nilai perusahaan dikarenakan kegiatan manajemen laba benarbenar memberi investor pandangan dalam menilai perusahaan lebih baik. Kedua, kepemilikan institusional sebagai variabel moderasi mampu memperlemah praktik manajemen laba yang dilakukan oleh pihak manajemen terhadap nilai perusahaan. Ketiga, kepemilikan manajerial tidak mampu memoderasi manajemen laba dengan nilai perusahaan. Kepemilikan manajerial sebagai salah satu upaya untuk internal control tidak dapat melakukan fungsi controlling dan managing perusahaan untuk meningkatkan nilai perusahaan. Keempat, komisaris independen juga tidak mampu memperlemah tindakan manajemen untuk melakukan manajemen laba. Hal ini dapat terjadi karena ketentuan minimum komisaris independen dirasa belum mampu untuk mendominasi dan memberikan pengaruh dalam pengambilan kebijakan yang dilakukan oleh dewan komisaris. Kesimpulan terakhir, reputasi auditor tidak mampu memoderasi 
hubungan antara manajemen laba dan nilai perusahaan. Praktik manajemen laba yang bebas dari kesalahan materialitas tidak akan menimbulkan konsekuensi hukum yang diderita perusahaan.

Studi ini memiliki beberapa peluang untuk dikembangkan. Pertama, studi antar negara menjadi isu yang menarik namun membutuhkan tantangan dalam hal perolehan data. Kedua, penggunaan data dengan serial waktu yang panjang juga akan menghasilkan temuan yang lebih tegar, karena informasi laba tidak selalu konsisten relevansinya, tergantung isu lain yang memengaruhi relevansi. Ketiga, studi ini bisa dikembangkan dengan menggunakan kemampuan prediksi manajemen laba dan tata kelola untuk melihat kinerja saham di masa mendatang. Isu tersebut penting mengingat prediktabilitas adalah salah satu bagian dari kualitas fundamental laporan keuangan.

\section{REFERENCES:}

Abbas, A. dan U. Ayub. 2019. Role of Earnings Management in Determining Firm Value: An Emerging Economy Perspective. International Journal of Advanced and Applied Sciences, 6, 103-116.

Alzoubi, E.S.S. 2016. Ownership Structure and Earnings Management: Evidence from Jordan. International Journal of Accounting and Information Management, 24 (2), 135-161.

Balsam, S., E. Bartov, dan C. Marquardt. 2002. Accrual Management, Investor Sophistication, and Equity Valuation: Evidence from 10-Q Fillings. Journal of Accounting Research, 40(4), 987-1012.

Brigham, E.F. dan P. R. Daves. 2007. Intermediate Finance Management. Ninth Edition. Thomson Learning Academic Resource Center.

Fama, E.F. dan M.C. Jensen. 1983. Agency Problems and Residual Claims. Journal of Law \& Economics. XXVI.

Gujarati, D. 2003. Ekonometrika Dasar (Terjemahan Sumarno Zein). Jakarta: Erlangga.

Gunny, K.A. 2010. The relation between earnings management using real activities manipulation and future performance: Evidence from meeting earnings benchmarks. Contemporary Accounting Research, 27(3), $855-888$.

Herawaty, V. 2008. Peran Praktek Corporate Governance Sebagai Moderating Variabel dari Pengaruh Earning Management Terhadap Nilai Perusahaan. Jurnal Akuntansi dan Keuangan, 10(2), 97-108.

Jara, M. dan F.J. López. 2011. Earnings management and contests for control: An analysis of European Family Firms. Journal of Centrum Cathedra, 4(1), 100-120.

Jiambavo, J. 1996. Discussion of Causes and Consequenses of Earnings Manipulation. Contemporary Accounting Research, 13, 37-47.

Kamil, F. dan D.W. Hapsari. 2014. Pengaruh Manajemen Laba Terhadap Nilai Perusahaan dengan Mekanisme Corporate Governance sebagai Variabel Moderasi. eProceeding of Management (Telkom University), 1(3). $\quad$ https://libraryeproceeding.telkomuniversity.ac.id/index.php/management/article/view/3266/3124 diakses 28 Desember 2020.

Klein, A. 2002. Audit Committee, Board of Directors Characteristics and Earnings Management. Journal of Accounting and Economics. 33, 375-400.

Lestari, P. P., dan N. Cahyonowati. 2013. Pengaruh Good Corporate Governance Terhadap Kinerja Perusahaan (Studi Empiris pada Perusahaan Jasa non Keuangan yang terdaftar di Bursa Efek Indonesia Tahun 20092011). Diponegoro Journal of Accounting, 2(4), 418-430.

Midiastuty, P. dan Mas'ud, Machfoedz, 2003. Analisis Hubungan Mekanisme Corporate Governance dan Indikasi Manajemen Laba. Seminar Nasional Akuntansi VI.

Peasnell, P., P. Pope, dan S. Young. 2000. Board monitoring and earnings management: Do outside directors influence abnormal accruals? Working Paper, Lancaster University. 
Rahmawati, A. dan M.N. Putri. 2020. Peran Good Corporate Governance Dalam Memoderasi Pengaruh Manajemen Laba Terhadap Nilai Perusahaan. Jurnal Riset Akuntansi dan Manajemen, 9(1), 63-75.

Ridwan, M., dan A. Gunardi. 2013. Peran Mekanisme Corporate Governance sebagai Pemoderasi Praktik Earnings Management Terhadap Nilai Perusahaan. Trikonomika, 12(1), 49-60.

Rudiawarni, F.A., D. Sulistiawan, dan Y.K. Feliana. 2017. When is earnings management really good news? Evidences from Indonesia. International Journal Trade and Global Markets, 10(1), 47-57.

Scott, R.W. 2015. Financial Accounting Theory. Seventh Edition. Pearson Prentice Hall: Toronto.

Shleifer, A. dan R.W. Vishny. 1986. Greenmail, White Knights, and Shareholders' Interest. Rand Journal of Economics, 17(3), 293-309.

Sinarwati, N.K. 2010. Mengapa Perusahaan Manufaktur yang Terdaftar di BEI Melakukan Pergantian Kantor Akuntan Publik?. Kumpulan Makalah Simposium Nasional Akuntansi XIII, Purwokerto: hal 1-20.

Sulistyanto, S. 2018. Manajemen Laba: Teori dan Model Empiris. Cetakan Kedua. Jakarta: PT Grasindo.

Susanto, Y.K. 2013. The Effect of Corporate Governance Mechanism on Earnings Management Practice. Jurnal Bisnis dan Akuntansi, 15(2), 157-167.

Susanto, Y.K., Pradipta, A., \& Cecilia, E. 2019. Earnings Management: ESOP and Corporate Governance. Academy of Accounting and Financial Studies Journal, 23(Spesial Issue 1).

Susanto, Y.K., Pirzada K., \& Adrianne S. 2019. Is tax aggressiveness an indicator of earnings management? Polish Journal of Management Studies, 20(2), 516-527.

Susanto, Y.K., Pradipta, A., \& Esther, S. 2021. Audit Decision: Interaction between Earnings Management and Audit Specialization. Academy of Accounting and Financial Studies Journal, 25(1), 1-8.

Tarmidi, D., dan E. Murwaningsari. 2019. The Influence of Earnings Management and Tax Planning on Firm Value with Audit Quality as Moderating Variable. Research Journal of Finance and Accounting, 10(4), 49-58.

Vafeas, N. 2000. Board Structure and The Informativeness Of Earnings. Journal of Accounting and Public Policy, 19, 139-160.

Yuniarti, E., Mukhtaruddin, dan H. Nadia. 2017. Effect on Value Earnings Management Company with Good Corporate Governance Practices as Moderating Variable. SHS Web of Conferences. 34. 04007. 10.1051/shsconf/20173404007. 
